\title{
Acidentados e remediados: a lei de acidentes no trabalho na Piracicaba da Primeira República (1919-1930).
}

\section{Eduardo Luís Leite Ferraz ${ }^{l}$}

Resumo: O presente artigo analisa como a lei de acidentes de trabalho (decreto n. 3.724 , de 15 de janeiro de 1919, regulamentado pelo decreto n. 13.498, de 12 de março de 1919) foi implementada na cidade de Piracicaba/SP ao longo da década de 1920. O trabalho investiga, mediante análise dos processos de acidente de trabalho, a significação da norma para patrões e empregados, os acidentes ocorridos, os trabalhadores envolvidos, o trâmite do processo judicial e os resultados práticos obtidos pelos trabalhadores acidentados. Além da bibliografia relativa à legislação e ao operariado da Primeira República, fizemos uso de processos de Inquéritos Policiais sobre Acidente no Trabalho (IPAT) e Autos de Ação Sumária de Acidente no Trabalho (ASAT), que se encontram no "Espaço Memória" do Centro Cultural Martha Watts, localizado no campus Centro da Universidade Metodista de Piracicaba.

Palavras- chaves: Acidentes no trabalho, Primeira República, Direito Social

Abstract: This article examines how the law of workplace accidents (Decree 3724 of 15 January 1919, regulated by Decree 13.498 of 12 March 1919) was implemented in the city of Piracicaba-SP during the 1920s. The paper investigates, through analysis of cases of accidents at work, the significance of the norm for employers and employees, accidents, workers involved, the procedure of the judicial process and the practical results obtained by the injured workers. In addition to the literature on the law and the labor of the First Republic, we use procedures on Accident Investigation Officers at Work and Action of Accident at Work, which are at the "Espaço Memória" do Centro Cultural Martha Watts, located on the central campus of the Universidade Metodista de Piracicaba.

Keywords: accident at work, First Republic, Social Law

\section{LeI de aCIDENTES e O PACTO liberal da PRIMEIRA RePÚBlica}

Os processos judiciais têm se revelado nos últimos anos importantes fontes para a história das relações de trabalho, mas são particularmente relevantes para o estudo dos acidentes. Sem a pretensão de alcançar a suposta verdade contida num substrato fático objetivo ou "o que verdadeiramente aconteceu", pode o historiador encontrar nas fontes judiciais não só os elementos reveladores do modo pelo qual se travavam as relações sociais

\footnotetext{
* O autor do presente trabalho é bolsista da FAPESP.

${ }^{1}$ Doutorando em História Social pela Universidade de São Paulo. Mestre em Educação e graduado em Direito e História pela Universidade Metodista de Piracicaba. Email: ellferraz@yahoo.com.br.
} 
no mundo do trabalho, as diferentes representações dos atores envolvidos, as conexões inerentes ao dinâmico processo da luta de classes, mas também as percepções dos agentes do Estado que, a partir da lei de acidentes, começaram a interferir, ou talvez mesmo participar, das tensões inerentes às relações de trabalho.

A promulgação das três primeiras leis do trabalho no Brasil (lei de acidentes de trabalho, lei de férias e código de menores) foi acompanhada de perto pelos homens de negócios ligados à indústria brasileira ${ }^{2}$. O projeto de lei sobre acidentes de trabalho, apresentado pelo senador paulista Adolfo Gordo, foi particularmente bem recebido pelo Centro Industrial Brasileiro - órgão de representação do setor industrial -, declarando-se este "prontamente favorável à adoção de regulamentação específica sobre um dos 'mais espinhosos problemas sociais' da indústria moderna ${ }^{3}$. O projeto de autoria do senador paulista havia sido apresentado em 1915, mas estava abandonado. Em razão das mobilizações operárias de 1917, fora retomado ${ }^{4}$.

A respeito das greves e mobilizações operárias, destaca Luiz Werneck Vianna que elas se iniciam já no início do século, 1901, e têm o seu auge em 1917 e 1919. Os operários tinham uma pauta de reivindicações que incluía jornada de 8 horas, aposentadoria, regulamentação do trabalho do menor, da mulher, direito a férias e horas extras, bem como seguro contra acidentes ${ }^{5}$. O Congresso Operário de 1906, ligado ao sindicalismo revolucionário, já colocava a questão dos acidentes de trabalho, refutando a atuação do Estado mediante a lei e responsabilizando o patrão pelo evento:

\begin{abstract}
considerando que o responsável dos acidentes no trabalho é sempre o patrão; e considerando que as leis decretadas em prol dos trabalhadores sobre esta matéria não têm nunca execução, são letra morta; o primeiro Congresso Operário Brasileiro aconselha aos sindicatos que sempre que qualquer desastre se verifique, eles arbitrem a indenização que o patrão tem de pagar, forçando-o a isso pela ação direta 6 .
\end{abstract}

Vianna entende que as mobilizações de 1917 a 1919 precipitaram a legislação social brasileira da década seguinte, incluindo aí, naturalmente, a lei de acidentes de trabalho de 1919. Ele considera que a legislação trabalhista brasileira - inaugurada pela lei de acidentes

\footnotetext{
${ }^{2}$ LIMA, Marcos Alberto Horta. Legislação e Trabalho em Controvérsias Historiográficas: o projeto político dos industriais brasileiros (1919-1930). Tese de Doutorado (História). Campinas: IFCH/Unicamp, 2005. p. 75.

${ }^{3}$ Ibidem, p. 76.

${ }^{4}$ GOMES, Ângela Maria de Castro. Burguesia e trabalho: política e legislação social no Brasil 1917-1937. Rio de Janeiro: Editora Campus Ltda., 1979. p. 65.

${ }^{5}$ VIANNA, Luiz Werneck. Liberalismo e sindicato no Brasil. 2. ed. Rio de Janeiro: Paz e Terra, 1978. p. 51.

${ }^{6}$ Apud VIANNA, Luiz Werneck, op. cit., p. 52.
} 
- vem consolidar o fim do pacto liberal inaugurado pela Constituição de 1891, fim esse que será coroado pela emenda constitucional de 1926. Através da lei de acidentes e das que a seguiram, o Estado ingressaria de vez nas relações privadas, inaugurando uma nova fase da história, e particularmente da história jurídica brasileira. A partir daí as relações de produção no Brasil não estariam mais sujeitas exclusivamente à livre iniciativa e ao livre contrato, contando com a decisiva intervenção estatal. O Código Civil deixaria de ser a lei norteadora das relações de produção, deslocado pelo Direito Social emergente: o Direito do Trabalho.

Samuel Fernando de Souza aponta a lei de acidentes de trabalho como o marco legislativo inaugurador do Direito do Trabalho no Brasil:

A publicação da Lei de Acidentes de Trabalho foi um passo importante para o processo de regulamentação das relações de trabalho no Brasil. Ela teria definido o direito do trabalho como ramo separado do Código Civil brasileiro, passando-se a considerar o acidente decorrência de riscos próprios do ambiente de trabalho industrial, assegurando ao operário o direito à reparação ${ }^{7}$.

Segundo Vianna, o fim do pacto liberal das classes hegemônicas e a emergência de um novo Direito, mais de acordo com as necessidades das classes trabalhadoras, estariam ligados às pressões das classes subalternas ${ }^{8}$. Mas a situação talvez seja um pouco mais complexa, particularmente quanto à lei de acidentes. Sustenta Marcos Horta Lima:

Luís Werneck Vianna concluiu de forma equivocada que os industriais brasileiros foram contrários a toda medida legal preconizada pelo Estado regulamentando as relações entre capital e trabalho. No caso da lei de acidentes de trabalho, observamos que ocorreu exatamente o oposto. Os industriais não apenas foram favoráveis à adoção da lei como participaram de sua elaboração e implantação ${ }^{9}$.

Ângela de Castro Gomes destaca a participação ativa da bancada gaúcha totalmente contrária à implementação de uma legislação social regulatória do trabalho no Brasil - nas discussões e na posterior aprovação da lei de acidentes de trabalho. A respeito dos gaúchos, diz que "eram contrários, por doutrina, à legislação sobre o trabalho, mas concediam, na prática, quando a legislação se referia a acidentes de trabalho e à proteção às mulheres e menores" $^{10}$. Não deixa de ser significativa esta posição aparentemente ambígua

\footnotetext{
${ }^{7}$ SOUZA, Samuel Fernando de. "Coagidos ou subornados": trabalhadores, sindicatos, Estado e as leis do trabalho nos anos 1930. Tese de Doutorado (História). Campinas: IFCH/Unicamp, 2006. p. 32.

8 "A locação de serviços do Código Civil vai ceder lugar ao emergente Direito do Trabalho, retificando-se o pacto liberal por pressão das classes subalternas." VIANNA, Luiz Werneck, op. cit., p. 61.

${ }^{9}$ LIMA, Marcos Alberto Horta. Legislação e Trabalho..., op. cit., p. 76.

${ }^{10}$ GOMES, Ângela Maria de Castro. Burguesia e trabalho..., op. cit., p. 77.
} 
dos parlamentares gaúchos, contrários à adoção de uma legislação trabalhista e favoráveis à lei de acidentes. Mas a autora a explica nos seguintes termos:

O fato de ser exatamente a proteção às mulheres, aos menores e aos inválidos (os acidentados) os aspectos da legislação aceitos pelos gaúchos não deixa de ser sugestivo. Isto porque nos dois primeiros casos trata-se de elementos que não são cidadãos (as mulheres e os menores não votam) e no último caso trata-se daqueles que, praticamente, se retiram do mercado de trabalho. Assim, a intervenção do Estado está se fazendo em relação aos "desprotegidos" que estariam à margem do sistema político e, até mesmo, econômico" ${ }^{11}$.

Dessa forma, como ressalta Ângela de Castro Gomes, longe de representar uma "conquista dos trabalhadores", a lei de acidentes foi um dos expedientes encontrados pelas emergentes classes industriais da Primeira República para proteger os "desamparados" do sistema político, estando mais próxima da filantropia do que da conquista política do movimento operário organizado. Não se trata, nesse sentido, da constituição de uma esfera pública no interior das indústrias e dos locais de trabalho, mas da manutenção mínima de uma força de trabalho indispensável à reprodução do sistema produtivo. Para todos os efeitos, estava mantida a concepção liberal de mercado.

Com a nova lei de acidentes, seria possível calcular previamente a importância a ser indenizada ao operário em caso de acidente, ampliando o patrão o controle sobre o custo final da mercadoria, eliminando as incertezas do pagamento de quantidades aleatórias referentes às reparações, bem como aos custos envolvidos nos longos processos do regime jurídico estabelecido pelo Código Civil ${ }^{12}$. Marcos Horta mostra como o Centro Industrial do Brasil atuou intensamente no processo de edição da lei de acidentes, procurando amoldar o projeto inicial aos interesses dos industriais ${ }^{13}$. O interesse maior, segundo ele, era o de fixar o operário junto ao local de trabalho através de benefícios e obras sociais dispostos ao redor da indústria ${ }^{14}$.

Contemplando os interesses industriais, o projeto aprovado pela Comissão de Legislação Social foi o substitutivo n 239 , de 1918 , cuja relatoria ficou a cargo do deputado

\footnotetext{
${ }^{11}$ GOMES, Ângela Maria de Castro. Burguesia e trabalho..., op. cit., p. 77.

12 LIMA, Marcos Horta. Legislação e trabalho..., op. cit., p. 77.

${ }^{13}$ Marcos Alberto Horta Lima cita o Relatório da Diretoria do Centro Industrial, do qual consta: "Esse projeto, depois de várias modificações, nas quais este Centro, diretamente, ou por intermédio de seu presidente efetivo e secretário-geral assiduamente colaborou, de modo a torná-lo menos oneroso ao patronato brasileiro e mais eficiente nas vantagens concedidas ao operariado nacional, é hoje a lei n. 3724, de 15 de Janeiro de 1919, já regulamentada (Dec. n. 13.493, de 5 de Março de 1919 do mesmo ano)". Apud LIMA, Marcos Alberto Horta. Legislação e Trabalho..., op. cit., p. 76.

14 Ibidem, p. 75.
} 
Andrade Bezerra. O projeto original do senador Adolpho Gordo ( $n$ - 237) havia sido incorporado ao texto do projeto de Código do Trabalho (no 288), que encontrava dificuldades de aprovação. Andrade Bezerra apresenta então o seu substitutivo, que também figuraria na primeira parte de um Código. Ante as dificuldades e críticas à aprovação global do Código, o substitutivo consegue furar o bloqueio imposto pelos deputados quanto à totalidade da legislação trabalhista, e é aprovado como lei especial ${ }^{15}$.

\section{Piracicaba da Primeira República: mercado de trabalho e ofícios}

Antes de entrar na questão da vigência da lei de acidentes na Piracicaba da década de 1920, é bom ressaltar aspectos do mercado de trabalho e das ocupações existentes na cidade ao longo da chamada Primeira República. A constituição inicial de um mercado de trabalho em moldes capitalistas em Piracicaba se dá entre o final do século XIX e o início dos anos $30^{16}$. As características marcantes desse mercado de trabalho são: a) a existência do colonato como relação de trabalho predominante no campo; b) o caráter segmentado do mercado de trabalho, diferenciando "campo" e "cidade".

O caráter segmentado do mercado de trabalho resulta, de um lado, dos vínculos mais permanentes de grande parcela da força de trabalho com as atividades rurais e com a própria vida rural. Por outro, pela pouca expressividade da força de trabalho urbana disponível ao capital. A pequena produção mercantil prevaleceu no cenário urbano piracicabano até a década de 1920, momento em que surgem os primeiros germens daquilo que viria a ser um importante núcleo de atividades industriais ligadas à agroindústria brasileira $^{17}$. A especificidade da região residia na tradicional e forte presença da lavoura de cana-de-açúcar, que impunha a instalação na própria região das atividades voltadas para sua transformação (produção de açúcar, álcool e aguardente). Podemos ainda destacar para a

\footnotetext{
${ }^{15}$ RIBEIRO, Maria Thereza Rosa. "Itinerário da construção do risco e segurança na sociedade brasileira." Sociedade e Estado, Brasília, v. 21, n. 3, p. 752-751, set/dez/2006.

${ }^{16}$ MALUF, Renato Sérgio (coord.). Aspectos da constituição e desenvolvimento do mercado de trabalho em Piracicaba. Piracicaba: Universidade Metodista de Piracicaba, 1984. p. 5.

${ }^{17}$ Ibidem, p. 6. "Um acontecimento que irá ter um enorme significado para o desenvolvimento desse embrião manufatureiro metal-mecânico diz respeito à fundação, em 1920, em Piracicaba, da Oficina Dedini, pelos irmãos Mário e Armando Dedini." NEGRI, Barjas. Apud MALUF, Renato Sérgio, op. cit., p. 29.
} 
cidade de Piracicaba e região a coexistência da atividade canavieira com a cafeicultura em expansão em todo o interior de São Paulo ${ }^{18}$.

No campo, concentrava-se o fundamental das atividades econômicas da época, que por suas características resultava na localização da principal parcela da população na zona rural. À cidade correspondia o papel de servir como uma extensão do campo, no sentido de nela estarem parte do beneficiamento e a comercialização de produtos agrícolas, a prestação de serviços e a burocracia pública, além de incipientes atividades industriais de pequeno porte. Destaca-se em primeiro lugar o fato de já possuir duas grandes unidades de processamento de cana-de-açúcar (Engenho Central e Monte Alegre), de caráter mais urbano, prenunciando uma importante transformação que resultará no predomínio absoluto das usinas em substituição aos pequenos engenhos rurais que eram dominantes neste período. O segundo destaque fica por conta de uma grande unidade têxtil (Boyes) que, afora sua importância como empregadora, poucos desdobramentos terá no conjunto das atividades econômicas da região.

As demais atividades urbanas compunham um quadro comum de pequenos e médios estabelecimentos $^{19}$. Esses estabelecimentos urbanos conhecem uma ampliação e diversificação ao longo da década de 1920 e da primeira metade da de $1930^{20}$. Quanto aos grandes "engenhos urbanos", podemos dizer que eles são construídos numa região que à época era o grande centro da produção açucareira paulista, e que vive intensamente o processo de retomada da atividade canavieira a partir de 1875 . Em 1882, foi construído o Engenho Central de Piracicaba que, como o anterior, seria vendido em 1899 a um grupo

\footnotetext{
${ }^{18}$ MALUF, Renato Sérgio (coord.). Aspectos da constituição e desenvolvimento do mercado de trabalho em Piracicaba. Piracicaba: Universidade Metodista de Piracicaba, 1984. p. 5.

19 Ibidem, p. 6.

${ }^{20}$ Para o ano de 1922, a distribuição dos estabelecimentos industriais em Piracicaba se faz do seguinte modo: 25 serrarias e carpintarias, 2 estabelecimentos de beneficiamento de algodão, 2 para produção de sabão, sabonetes e perfumarias, 16 para licores, vinagre e vinho, 3 empresas de massas alimentícias, 12 de artefatos de couro e curtumes, 3 de carros de tração animal, 8 de balas e bombons, 20 de biscoitos e bolachas, 9 de móveis de madeira, 1 de instrumentos musicais e 22 de cal, telhas e tijolos. Fonte: CAPRI, Roberto. O Estado de São Paulo e seus municípios. Ed. Pocai e Weiss, 1922, p. 187. Citado por MALUF, Renato Sérgio. Aspectos da constituição..., op. cit., p. 34. Em 1936, a produção já havia se incrementado. Existiam em Piracicaba 12 serrarias e carpintarias, 3 oficinas de beneficiamento de café, 5 de arroz, 6 de algodão, 5 para produção de sabão, 1 para chapéu, 2 de cerveja, 6 de licores, vinagre e vinho, 3 de massas, 7 de café em pó, 4 oficinas mecânicas, 2 de arados, 11 de curtume e couro, 6 gráficas, 1 de bala e bombons, 22 fecularias, 1 de produtos farmacêuticos, 2 de gelo, 3 empresas de biscoitos e bolachas, 1 marmoraria, 2 de ladrilhos, 3 fundições, 19 para produção de móveis de madeira, 2 de fogos e armas, 3 de fogões, 2 caldeirarias, 3 de louças de barro, 6 de colchões, 3 de barris, 1 de instrumentos musicais, 1 de tecidos, 5 de vassouras e 15 de cal, telhas e tijolos. Fonte: NEME, Mário. Piracicaba 1936 - Documentário, p. 155-157. Citado por MALUF, Renato Sérgio. Aspectos da constituição..., op. cit., p. 34.
} 
francês (uma sociedade anônima com sede em Paris, de nome Société des Sucreries Brésiliennes). Em 1890, foi fundada outra grande fábrica em Piracicaba: o "engenho central" Monte Alegre ${ }^{21}$.

A fábrica de Santa Francisca ("Arethusina"), por sua vez, foi fundada em 1876, mudando posteriormente sua denominação para "Companhia Agrícola e Industrial Boyes". Desde a sua fundação, a fábrica já se destaca como uma unidade de produção de porte considerável para a época (com 50 teares, 2.500 fusos e 70 operários), contrastando, pois, com o padrão semiartesanal e familiar das demais unidades produtivas ${ }^{22}$. A produção têxtil da Boyes se destinava basicamente ao mercado de Piracicaba e região; a fábrica produzia o chamado tecido "roceiro", pano rústico muito difundido entre lavradores, e sacaria para os engenhos e usinas de açúcar ${ }^{23}$.

Pela sua magnitude, a Arethusina fugia dos padrões industriais da Primeira República, cuja marca eram as pequenas empresas, de mínima capitalização e base técnica artesanal ${ }^{24}$. Para o ano de 1919, as indústrias de 200 a 499 empregados, dentre as quais a fábrica piracicabana se inclui, representavam apenas $1,1 \%$ do total em São Paulo e $1,8 \%$ no Rio de Janeiro $^{25}$. Fausto salienta que comparada à oficina metalúrgica, gráfica, a pequena empresa de mobiliário, a indústria têxtil é o único ramo realmente fabril, apresentando maior grau de mecanização, de concentração de operários na unidade, e de utilização de energia elétrica em lugar da pequena máquina a vapor ${ }^{26}$.

\footnotetext{
${ }^{21}$ RAMOS, Pedro. "História econômica de Piracicaba (1765-1930)": as particularidades do complexo canavieiro paulista". In: TERCI, Eliana Tadeu (org.). O desenvolvimento de Piracicaba: história e perspectivas. Piracicaba: Editora Unimep, 2001. p. 74.

${ }^{22}$ MALUF, Renato Sérgio. Aspectos da constituição..., op. cit., p. 33.

${ }^{23}$ Ibidem, p. 35. Em 1912, o montante de seu capital era de 1.940:000\$0000 e a indústria tinha cerca de 300 operários. Com esse capital, a Arethusina figurava então como um dos 102 maiores empreendimentos industriais do Brasil daquele ano, representando 1,1\% do total dos empreendimentos e, em termos de pessoal ocupado, figurava entre os 163 maiores empreendimentos industriais, representando 1,6\% do total. DEAN, Waren. Apud TERCI, Eliana Tadeu. Elites e espaço público: a cidade desejada. Trabalho apresentado no VIII Congresso Internacional da Brasa Vanderbilt University - Tennessee.

${ }^{24}$ FAUSTO, Boris. Trabalho urbano e conflito social. São Paulo: DIFEL, 1983. p. 105.

${ }^{25}$ Recenseamento de 1920, citado em FAUSTO, Boris. Trabalho urbano..., op. cit., p. 106.

${ }^{26}$ Ibidem, p. 107.
} 


\section{UMA LEI AMBÍGUA: ENTRE AS GARANTIAS JURÍDICAS E O LIMITE MATERIAL}

Em meados da década de 1920, o repórter e jornalista de "O Estado de São Paulo", Antônio dos Santos Figueiredo ${ }^{27}$, numa obra intitulada A Evolução do Estado no Brasil (publicada em 1926), faz alguns comentários a respeito da lei de acidentes no trabalho e do seu significado para o operariado brasileiro. Dentre outras coisas, critica o autor da lei, o deputado por Pernambuco, Dr. Andrade Bezerra. Afirma que sua obra, os Comentários sobre a lei de acidentes no trabalho, é excelente do ponto de vista teórico, porém se ressente "da falta de notícias exatas do meio e das pessoas de quem depende a boa execução da lei" ${ }^{28}$. “De certo [o deputado] ouviu os sócios velados dos Centros Industriais, carteou-se com eles, pediu as luzes de sua experiência, para, com sua bagagem científica, apresentar a lei" ${ }^{29}$.

O deputado ressalta que a nova lei iria contribuir na educação social do operariado, levando-o "a conhecer o seu próprio direito" ${ }^{30}$. O jornalista diz prezar "muito o parecer do jurisconsulto pernambucano", mas não concorda com seus fundamentos. Afirma que o operário jamais conhecerá o seu próprio direito por meio da nova lei. Isso porque as classes dirigentes se incumbem de impedir que ele vá até o juiz para apresentar a queixa ${ }^{31}$.

O artigo 19 da lei estabelecia que todo acidente de trabalho deveria ser "imediatamente comunicado à autoridade policial do lugar". A autoridade deveria comparecer "sem demora ao lugar do acidente" e àquele em que se encontrasse a vítima, tomando as suas declarações, as do patrão e as das testemunhas, para lavrar o respectivo auto." (art. 19). Esse artigo (e o art. 42 do decreto, que o repetia) era a base de todo o processo de acidentes no trabalho. Tudo começava com a comunicação da ocorrência ao delegado. A comunicação era obrigatória. Não havia, nesse ponto, discricionariedade ou arbitrariedade por parte da autoridade, mas uma obrigação decorrente de lei. O objetivo era o de que o conhecimento do acidente chegasse efetivamente à autoridade pública que daria início a toda a dinâmica processual.

\footnotetext{
${ }^{27}$ Paulistano, nascido em 1890, o jornalista era um interessado pelas questões sociais e pelo movimento operário. Filho de operários, bacharela-se em Direito em 1916.

${ }^{28}$ Trecho de $A$ Evolução do Estado no Brasil - intitulado "A legislação social e os limites de sua aplicação". In: PINHEIRO, P. S.; HALL, Michael M. A classe operária no Brasil. Volume II, p. 321.

${ }^{29}$ Ibidem.

${ }^{30}$ A frase é do próprio deputado, Dr. Bezerra, reproduzida pelo jornalista. Ibidem.

31 Ibidem.
} 
Através da comunicação, o fato do acidente deveria deixar o ambiente doméstico da oficina, indústria ou propriedade rural e ingressar no mundo público, para que a instituição competente desse início às consequências legais e jurídicas decorrentes do fato. Por isso ela era tão importante, e a lei a cercava de garantias, transformando-a numa espécie de ato solene.

O patrão tinha a obrigação, e o operário o direito de comunicar, mas a lei abria a possibilidade de comunicação a "qualquer outro". Essa abertura tinha por objetivo impedir a inviabilização da comunicação inauguradora do procedimento. O patrão naturalmente não teria razões para iniciar um procedimento contra si mesmo, e o operário poderia se sentir constrangido ou mesmo sofrer ameaças de seu patrão para que não noticiasse o acidente à polícia. Permitindo a possibilidade da comunicação a "qualquer outro", a lei procurava garantir ao trabalhador a comunicação do fato à autoridade competente.

Mas para o jornalista Figueiredo, na prática a teoria era outra... Diz em seu texto que o artigo 19 era constantemente violado pelos patrões:

Ocorrido o acidente, um operário é ferido leve ou gravemente. Que faz a direção da casa em que trabalha? Chama a assistência? Não; chamar a assistência seria dar o alarme do fato, seria sujeitar-se à lei $[. . .]^{32}$.

Segundo ele, os patrões tinham um dado procedimento:

transferem o ferido imediatamente para o escritório da fábrica, onde ele recebe os primeiros e às vezes os únicos curativos. Um automóvel do estabelecimento leva-o para a casa. E, dias depois, lá está ele a trabalhar sem se curar convenientemente ${ }^{33}$.

Quanto à possibilidade de o operário poder comunicar o fato à polícia, ironiza o jornalista:

Pior! Se tiver o topete de fazer escândalo em torno do seu caso, quer dizer, se der algum passo para conhecer o seu próprio direito, como disse o legislador, está condenado para todo o sempre. Passa para a lista negra dos industriais, que formaram, depois de promulgada a lei, uma lista secreta contra os audaciosos. Não é mais aceito - nem para a fábrica em que se inutilizou, temporária ou definitivamente, nem em outra qualquer. [...] Serão tomados como agitadores, e a polícia, serva humílima e dedicada dos industriais, tomará nota dos seus precedentes e dos seus defeitos ${ }^{34}$.

O jornalista põe em evidência um aspecto digno de nota: para que a lei de fato fosse aplicada, o operário dependia em primeira instância da polícia. Mas aí entra a questão de

\footnotetext{
32 "A legislação social e os limites de sua aplicação", op. cit., p. 322

33 Ibidem.

${ }^{34}$ Ibidem.
} 
classe. Os delegados não eram tradicionalmente grandes aliados dos trabalhadores. Na perspectiva realista do jornalista, a polícia, serva submissa da classe patronal, se incumbiria de tomar as providências para que a vítima de acidentes fosse para sempre estigmatizada ante a classe dos industriais. Mesmo que a polícia viesse a saber do acidente, isso não seria problema para os patrões:

Abafar inquéritos é coisa corriqueira nos nossos anais. Basta um pedido de político para arrefecer o entusiasmo da autoridade. Não custa nada, aos industriais, fazerem uso da sua influência, a fim de se eximirem das responsabilidades, oriundas dos pleitos judiciais ${ }^{35}$.

E arremata o jornalista: "raramente, no nosso foro, um operário saiu vencedor numa lide contra os patrões" ${ }^{\prime 36}$. A análise do jornalista Figueiredo, embora não especifique, revela a situação do operariado na cidade de São Paulo. Por certo os trabalhadores se viram em dificuldades para instrumentalizar uma lei contra os seus patrões, mas não é de todo correto que os operários raramente saíam vencedores das lides judiciais, pelo menos no caso de Piracicaba.

Dezenas de ações trabalhistas por acidente de trabalho tiveram curso na cidade ao longo da década de 1920, e na maioria delas o que se vê é um resultado judicial favorável aos trabalhadores urbanos e rurais. É claro que não se pode ver na lei um instrumento de libertação da classe operária piracicabana. Mas é igualmente inegável que, mediante a lei, muitos trabalhadores conseguiram fazer valer na Justiça suas posições, defender seus interesses e conseguir resultados favoráveis, pelo menos do ponto de vista judicial.

\section{1. "FATO dO tRABalho"}

Do ponto de vista jurídico, a lei dava bastante proteção ao operariado. Em primeiro lugar, previa o direito à indenização independentemente da aferição da culpa, como comentamos acima. O procedimento judicial não se prestava a investigar a responsabilidade do patrão pelo acidente. A lei brasileira, inspirando-se na legislação francesa, adotou a chamada teoria do "fato do trabalho". Preconizava o artigo 2 ㅇ da lei que o patrão estava obrigado a pagar indenização ao operário ou à sua família quando o acidente ocorresse

\footnotetext{
35 “A legislação social e os limites de sua aplicação", op. cit., p. 322.

${ }^{36}$ Ibidem.
} 
"pelo fato do trabalho ou durante este." O acidente era visto como uma espécie de fato natural e próprio da atividade laborativa.

Esta era a regra geral, mas tanto a lei quanto o decreto regulamentador estabeleciam exceções nos casos de força maior e dolo da própria vítima (ou de terceiro). Em outras palavras, se o acidente decorresse de um evento extraordinário e imprevisto - não diretamente ligado à atividade laboral - ou fosse intencionalmente praticado pela vítima ou terceiro (com o intuito, por exemplo, de receber a quantia legalmente fixada), o acidente não deveria ser considerado passível de indenização. Em nenhum dos processos analisados foi constatada a alegação de "força maior" ou "dolo" como forma de escusa por parte dos patrões para o cumprimento da lei.

O parágrafo único do artigo 20 do decreto dota o operário de uma garantia contra a possibilidade de alegação indiscriminada de força maior pelos patrões ao preceituar que "não constitui força maior a ação das forças naturais, quando ocasionada ou agravada pela instalação do estabelecimento, pela natureza do serviço ou pelas circunstâncias que efetivamente o cercarem." Uma vez ligado ao trabalho, cabia ao trabalhador o direito à indenização pelo acidente.

Nos processos analisados, podemos claramente ver como os acidentes decorriam da atividade do trabalho. O operário Josias Fischer despencou de um andaime de vinte metros em 1926, quando realizava um trabalho de reconstrução da cúpula da igreja da Nossa Senhora da Boa Morte ${ }^{37}$. Os despencamentos de andaimes eram bastante frequentes. $\mathrm{O}$ carpinteiro Silvestre Selvagio, de 66 anos, também despencou de um, fraturando a clavícula, quando prestava serviços para o seu patrão Hugo Bergamin em $1920^{38}$. No ano seguinte, em 25 de novembro de 1921, José Cristão (ou Tristão) trabalhava numa escada de quatro metros de altura, esticando um "fio troly", quando o cordão do "moitão" que o segurava veio a se romper, provocando a sua morte ${ }^{39}$.

Em 1920, Alberto Brasso trabalhava numa construção na Rua da Glória quando encostou em um fio de alta tensão. Estava sobre um andaime a apenas trinta centímetros do fio. Uma das testemunhas relata o ocorrido:

\footnotetext{
${ }^{37}$ Caixa 15/B do 10 Ofício Cível de Piracicaba. IPAT- Izaías Emílio Romano (patrão) x Josias Fischer (vítima). 1926.

${ }^{38}$ Caixa 22/B do do 1o Ofício Cível de Piracicaba. ASAT - Silvestre Selvagio (operário) x Hugo Bergamim.1920.

${ }^{39}$ Caixa 15/A do 10 Ofício Cível de Piracicaba. José Cristão (Tristão) x Bygton e Companhia (da Empresa Elétrica de Piracicaba). 1921.
} 
Pôs-se a descrever [...] as peripécias de uma fita cinematográfica e ao fazer um gesto largo com o braço esbarrou a mão em um dos fios condutores de energia. Viu a vítima puxar com força a respiração, ficar com o corpo duro e, perdendo o equilíbrio, cair do andaime, tremendo ${ }^{40}$.

O operário veio a falecer em decorrência da descarga elétrica. As situações de acidente eram as mais diversas. No mesmo ano de 1920, em 15 de outubro, Joaquina Camargo Ferreira, de 20 anos, prestava serviços na casa da sua ex-patroa, trabalhando no enceramento do assoalho de um dos cômodos. Colocou certa quantia de óleo de linhaça em uma lata sobre um fogareiro elétrico e, quando o líquido estava em ebulição, jogou sobre ele certa porção de aguarrás. Resultado: uma explosão, que deixou a jovem inteiramente queimada, vindo a falecer horas depois na Santa Casa de Misericórdia ${ }^{41}$.

O imprevisto da vida poderia aparecer nas situações cotidianas e aparentemente mais inofensivas. Joaquim Desidério, de 21 anos, transportava dez sacas de cal em uma carroça pela estrada que vai ao bairro de Serra Negra, quando o carro tombou despejando as sacas sobre ele. $O$ operário acabou falecendo por asfixia ${ }^{42}$.

As oficinas de Piracicaba eram constantemente palco de acidentes. José dos Santos, operário de uma marcenaria da Rua Moraes Barros em 1929, trabalhava com a máquina de cortar madeira quando teve um de seus dedos decepados ${ }^{43}$. O empregado de Emílio Bertozzi, dono da fábrica de massas "A Industrial”, também perdeu um dos dedos da mão direita na engrenagem ${ }^{44}$.

Os trabalhos agrícolas também eram ocasiões propícias aos acidentes. Pedro Cunha, funcionário da Companhia União dos Refinadores em 1923, guiava uma junta de bois que triava uma grade de discos sobre um terreno arado; tropeçou, caiu no chão e a grade passou por cima do seu corpo, causando-lhe ferimentos graves ${ }^{45}$. No mesmo ano, Júlio de Sousa, funcionário da Usina Santa Bárbara, feriu sua mão ao apalpar um motor elétrico para avaliar a temperatura deste ${ }^{46}$.

\footnotetext{
${ }^{40}$ Caixa 15/B do 1o Ofício Cível de Piracicaba. ASAT - Alberto Brasso (vítima, por seu representante) x Napoleão Belluco (patrão). 1920.

${ }^{41}$ Caixa 15/A do 1o Ofício Cível de Piracicaba. ASAT - Joaquina Camargo (vítima) x Da. Carolina Lima Aguiar (patroa). 1920.

${ }^{42}$ Caixa 22/A do 1o Ofício Cível de Piracicaba. AAT - Lázaro Dias Fernandes (patrão) x Joaquim Desidério (vítima).1922.

${ }^{43}$ Caixa 22/B do 1o Ofício Cível de Piracicaba. IPAT - João Zara (patrão) x José dos Santos. 1929.

${ }^{44}$ Caixa 22/B do 1o Ofício Cível de Piracicaba. IPAT - Eduardo Domingos (vítima) x Emílio Bertozi. 1925.

${ }^{45}$ Caixa 15/B do 10 Ofício Cível de Piracicaba. IPAT - Pedro Cunha x Companhia União dos Refinadores. 1923.

${ }^{46}$ Caixa 15/B do 1o Ofício Cível de Piracicaba. IPAT - Usina Santa Bárbara x Júlio de Sousa. 1923.
} 
A lei procurava resguardar o trabalhador das ameaças constantes do mundo do trabalho. Muitas vezes o operário não era o agente do acidente, decorrendo este de um fato externo e completamente alheio à sua vontade. É o caso de Antonio Francisco, que em 1920 trabalhava na construção do ramal ferroviário que ligaria Santa Bárbara a Piracicaba e foi atingido por uma pedra que se desprendeu de um barranco, causando-lhe lesões graves na cabeça e na perna direita ${ }^{47}$. É por isso que a lei previa indenizações não apenas para fatos do trabalho, mas também para acidentes ocorridos "durante o trabalho".

A concluir pelo número de ações, a atividade que mais provocou acidentes de trabalho na Piracicaba da década de 1920 foi certamente a construção da estrada de ferro da Companhia Paulista, inaugurada em 1922. Eliana Terci afirma que o ano de 1922 foi um ano de muitas comemorações na cidade pelo centenário da Independência; mostrava-se realmente um ano promissor aos piracicabanos, pois finalmente seria inaugurado o ramal da Companhia Paulista de Estradas de Ferro, ligando Piracicaba aos caminhos do comércio na capital paulista ${ }^{48}$. A estrada de ferro simbolizava o progresso e desenvolvimento da cidade, e a inauguração foi motivo de bastante orgulho na cidade.

\begin{abstract}
A ausência dessa via de acesso desestimulava o comércio e a indústria, afinal [como dizia o jornal de Piracicaba em 29 de julho de 1922] "a única estrada que nos punha em comunicação com a capital do Estado se achava no seu máximo estado de desorganização ${ }^{49}$.
\end{abstract}

Mas o sonho da elite piracicabana se fez à custa de muitos acidentes dos trabalhadores. Em maio de 1922, Emílio Rodrigues trabalhava descarregando terra de um vagão quando um companheiro resvalou a pá em sua mão, produzindo ferimentos ${ }^{50}$. Exatamente o mesmo acidente aconteceu com José Victorino ${ }^{51}$.

Ainda naquele maio de 1922, João Borges andava em um troly de linha do ramal Piracicaba-Santa Bárbara, da Companhia Paulista, quando o carro escapou por uma rampa, ganhando velocidade. A vítima se viu obrigada a atirar-se do troly para escapar do acidente mais grave, vindo a sofrer escoriações e contusão no quadril, tórax e face ${ }^{52}$. Luiz Lucas

\footnotetext{
${ }^{47}$ Caixa 15/B do 1o Ofício Cível de Piracicaba. ASAT - Antonio Francisco (vítima) x Domingos Ferreira Bento R. (patrão). 1920.

${ }^{48}$ Elites e espaço público..., op. cit.

${ }^{49}$ Ibidem.

${ }^{50}$ Caixa 15/B do 1o Ofício Cível de Piracicaba. ASAT - Emílio Rodrigues x Cia. de Estradas de Ferro Paulista. 1922.

${ }^{51}$ Caixa 22/A do 1 o Ofício Cível de Piracicaba. ASAT - Cia. Paulista x José Victorino. 1922

${ }^{52}$ Caixa 15/B do 1o Ofício Cível de Piracicaba. ASAT - João Borges x Cia. Paulista. 1922.
} 
também teve de se atirar de um vagão em movimento em 1922, e sofreu luxação escápuloumeral $^{53}$. Já Eugênio Silva sofreu ferimentos leves com o descarrilamento do vagão ${ }^{54}$.

\subsection{RESULTADOS DAS LESÕES E PREVISÃO DE INDENIZAÇÃO}

Os resultados podiam ser os mais variados: desde um simples ferimento produzido por uma lasca de pedra na planta do pé ${ }^{55}$ até as catastróficas mortes e perdas de membros do corpo. A lei e o regulamento estabeleciam as indenizações conforme o grau das lesões produzidas. Em caso de morte, o patrão deveria pagar o equivalente a três anos de salário da vítima, além das despesas com o funeral (art. 70 da lei e 18 do decreto). Nesse caso, teria direito à indenização o cônjuge sobrevivente e os herdeiros necessários, segundo a ordem estabelecida no Código Civil. Se a vítima só deixasse o cônjuge, a indenização seria reduzida para dois anos de trabalho.

Três anos também deveriam ser pagos se a vítima restasse total e permanentemente incapacitada (art. 8). O decreto 13.498 estabelece o conceito de incapacidade total e permanente como "a invalidez absoluta e incurável para qualquer serviço." A incapacidade podia ser parcial e permanente, o que dava à vítima direito à indenização de 5 a $60 \%$ daquela a que teria direito caso fosse total e permanente.

O decreto regulamentador trazia uma tabela para que os juízes e contadores pudessem ter um parâmetro das porcentagens a serem fixadas de acordo com o grau de gravidade da lesão. A perda de todo um membro deveria, assim, proporcionar uma indenização de 55 a 60\% (em relação à que teria direito se a incapacidade fosse total e permanente); a do antebraço, de 50 a 60\%; a da mão, de 45 a 60\%, e assim por diante. As lesões do lado direito do corpo deveriam proporcionar uma indenização maior que as do esquerdo, segundo a tabela.

O regulamento dizia que na fixação do quantum para a incapacidade parcial e permanente, o juiz deveria atentar para a natureza e incapacidade do operário, tendo em

\footnotetext{
${ }^{53}$ Caixa 15/B do 1o Ofício Cível de Piracicaba. ASAT - Companhia Paulista de Estradas de Ferro x Luiz Lucas. 1922.

${ }^{54}$ Caixa 22/A do 1o Ofício Cível de Piracicaba. ASAT - Cia. Paulista x Eugênio Silva.1922.

${ }^{55}$ Como o do operário Benedito Romão Fernandes, em 1922. Caixa 15/B do 1o Ofício Cível de Piracicaba. ASAT

- Benedito Romão Fernandes x Cia. Paulista. 1922.
} 
vista: a) faculdades de trabalho subsistentes; b) idade; c) inteligência; d) grau de instrução; e) iniciativa e energia moral; f) adaptação a outra profissão; g) segurança da acomodação à mesma profissão (art.21). Isso significava que ao lado de critérios objetivos, como idade e grau de instrução, a lei considerava critérios subjetivos como inteligência, "iniciativa" e "energia moral", o que poderia ser uma brecha para o rebaixamento do valor da indenização.

A lei estabelecia ainda outras garantias jurídicas como a impenhorabilidade do crédito, e sua condição privilegiada em relação aos demais débitos do patrão (art. 25 da lei e 27 do decreto). Isso significava que se o patrão se visse na impossibilidade patrimonial de satisfazer todos os seus débitos, os créditos oriundos do acidente teriam preferência sobre todos os outros. Tratava-se de uma garantia jurídica que permitiria ao operário ou à sua família receber em primeiro lugar.

\subsection{INDENIZAÇÃO ATRELADA AO SALÁRIO DA VÍTIMA E LIMITE INDENIZATÓRIO}

Embora a lei de acidentes conferisse algumas garantias jurídicas aos trabalhadores acidentados, essas garantias mostravam-se muito relativizadas se considerarmos dois aspectos: a vinculação da indenização ao salário da vítima e o limite indenizatório.

O critério básico para a fixação do valor da indenização era o salário da vítima. Isso significa que o direito à indenização não era apreciado em razão de uma concepção abstrata de dignidade humana ou direito ao próprio corpo, nem pela eventual negligência patronal pelas condições de trabalho dos seus operários, mas simplesmente pelo quantum salarial. Como na Primeira República os salários das classes operárias eram em geral bastante baixos, as indenizações decorrentes dos acidentes eram igualmente baixas.

Para os efeitos de indenização, o corpo de um operário que recebia um salário elevado valeria mais do que aquele que recebia pouco. Mesmo a indenização por morte deveria variar segundo o salário do operário, o que relativiza sobremaneira a noção de que a indenização poderia consistir numa penalidade imposta ao patrão.

Além disso, a lei era totalmente favorável aos interesses das classes patronais no que se refere à fixação de um teto indenizatório de dois contos e quatrocentos mil-réis por ano (2:400\$00/ano) (art. 6). O máximo que um patrão poderia pagar ao seu empregado como 
indenização às situações mais graves (morte ou invalidez total) chegaria à soma de 7:200\$00, considerando os três anos fixados pela lei. A lei retirava dos juízes poderes para aplicar uma indenização maior.

A lei considerava para efeitos de indenização 1 ano de trabalho como 300 dias. Para um trabalhador ter direito a uma indenização de 2:400\$00 ele deveria receber, portanto, um salário de $8 \$ 000 /$ dia. Mas não era essa a realidade da esmagadora maioria dos operários que participaram de ações por acidente de trabalho na Piracicaba da década de 1920.

Dos processos de acidente analisados, constatamos que a realidade dos salários não chegava aos $8 \$ 000$ diários, girando em torno dos $5 \$ 000^{56}$. Os salários mais altos observados são os do funcionário do Engenho Central, Antônio Monteiro Azevedo, em 1929 $(7 \$ 000 / \text { dia })^{57}$, do carpinteiro Silvestre Selvagio, em $1920^{58}$, e de Maximo Thomazi, marceneiro, ambos percebendo a quantia de $6 \$ 000 / \mathrm{dia}^{59}$. Os operários da Companhia de Estradas de Ferro Paulista não recebiam mais do que $5 \$ 000$ por dia pelo que faziam. Os funcionários da fábrica de tecidos Boyes S/A que foram vítimas de acidentes de trabalho ao longo da década de 1920 também não ganhavam mais do que $4 \$ 000$ por dia ${ }^{60}$.

O limite indenizatório de 7:200\$000 nunca era atingido. O Dr. Holger Jensen Kok pagou uma indenização de 3:900\$00 pela morte de seu funcionário que calçava uma tara de madeira quando a corrente se rompeu e o atingiu ${ }^{61}$. A família do operário José Cristão (ou Tristão), funcionário da Empresa Elétrica de Piracicaba e que trabalhava por $4 \$ 000 /$ dia, também não recebeu nem perto dos 7:200\$000 62 . A mãe de Joaquina Camargo Ferreira, vítima da explosão da aguarrás, recebeu $900 \$ 000$ de indenização ${ }^{63}$.

\footnotetext{
${ }^{56}$ Júlio de Sousa, empregado da Usina Santa Bárbara, percebia um ordenado de $4 \$ 700 /$ dia em 1923 . Antônio Francisco, construtor do ramal Santa Bárbara-Piracicaba em 1920 , recebia $3 \$ 500$ por seu dia de trabalho. 0 trabalhador agrícola Pedro Cunha, funcionário da Companhia União dos Refinadores em 1923, recebia apenas $2 \$ 800$ por dia de trabalho. Processos da caixa 15/B do 10 Ofício Cível de Piracicaba.

${ }^{57}$ Caixa 22/A do 10 Ofício Cível de Piracicaba. IPAT - Antônio Monteiro Azevedo x Engenho Central. 1929.

${ }^{58}$ Caixa 22/B do 10 Ofício Cível de Piracicaba. ASAT - Silvestre Selvagio (operário) x Hugo Bergamim (patrão).1920.

${ }^{59}$ Caixa 15/A do 10 Ofício Cível de Piracicaba. AAT (Autos de Acidente no Trabalho).

${ }^{60}$ Maria Fiorim, funcionária na fábrica de tecidos "Arethusina", da Boyes, e que teve seu dedo indicador direito dilacerado na engrenagem, recebia $105 \$ 000$ mensais (3\$500/dia). O jovem Guilherme Joós, de 14 anos, trabalhava para a mesma fábrica em 1919 por um salário de 1\$400/dia. Processos da caixa 22/B do 10 Ofício Cível de Piracicaba.

${ }^{61}$ Caixa 15/A do 10 Ofício Cível de Piracicaba. IPAT - José Corrêa de Lima (vítima) x Dr. Holger Jensen Kok.

${ }^{62}$ Caixa 15/A do 1o Ofício Cível de Piracicaba. José Cristão (Tristão) x Bygton e Companhia (da Empresa Elétrica de Piracicaba). 1921.

${ }^{63}$ Caixa 15/A do 1o Ofício Cível de Piracicaba. ASAT - Joaquina Camargo (vítima) x Da. Carolina Lima Aguiar (patroa). 1920.
} 


\section{O TRÂMITE JUDICIAL}

Como vimos, o procedimento destinado a impor ao patrão uma indenização por acidente de trabalho se iniciava com a comunicação do fato ao delegado de polícia. Elaborava-se então um inquérito policial para verificar as circunstâncias do acidente. $\mathrm{O}$ inquérito era a primeira etapa para a responsabilização do patrão quanto ao acidente, mas, tecnicamente, não se tratava ainda de procedimento judicial. A primeira peça do inquérito era uma portaria do delegado que registrava que havia chegado ao seu conhecimento um dado acidente. A portaria, todavia, era impessoal e não especificava quem havia sido o autor do comunicado.

Era então elaborado o "auto circunstanciado", a que fazem referência os artigos 19 da lei e 42 do decreto regulamentador, especificando o nome da empresa; o nome, "qualidade" e residência do patrão; o nome, "qualidade", residência, salário, idade, sexo, nacionalidade, grau de instrução e estado civil da vítima; além do lugar, hora e natureza do acidente, as circunstâncias que o cercaram, nomes e residências das testemunhas e dos eventuais beneficiários da indenização.

Em alguns processos, o patrão juntava espontaneamente os comprovantes de que havia prestado imediatamente os socorros médico, farmacêutico e hospitalar à vítima, conforme determinava o artigo 43 do decreto. Se não o fizesse, era intimado pelo escrivão da polícia para que procedesse à juntada. A lei dava um prazo de cinco dias (art. 43 do decreto), e se o patrão não fornecesse a documentação comprobatória, isso era certificado nos autos pelo escrivão. Após a elaboração do auto circunstanciado pelos escrivães da polícia, o inquérito era remetido ao delegado, que ordenava a realização do exame de corpo de delito.

Era então elaborado um "Auto de Corpo de Delito" com a conclusão do perito a respeito da natureza e gravidade da lesão. Se o exame estivesse de acordo com as regras técnicas, o delegado julgava pela sua procedência. Após isso, ordenava a remessa do inquérito e dos respectivos documentos ao juiz de Direito, conforme determinação do §1으 do art. 43 do regulamento e $\S 2 \circ$ do art. 19 da lei de acidentes. 
Recebidos os autos do inquérito pelo juiz competente para analisar o caso, iniciava-se a fase judicial do procedimento. A ação não tinha um autor, alguém que iniciava um procedimento na Justiça. O juiz competente para analisar o caso era o juiz cível, integrante da Justiça Comum (art. 22 da lei). Piracicaba tinha à época dois cartórios judiciais para a tramitação dos processos. Pelo que se depreende do conjunto documental do acervo analisado, o 1 o Ofício praticamente concentrou o julgamento dos processos de acidentes no trabalho ao longo da década de 1920.

O procedimento judicial era bastante enxuto. O objetivo da lei era obrigar os patrões ao pagamento sem a necessidade das longas verificações de culpa. Não há nos processos, por esse motivo, um contraditório bem definido, no qual a vítima e o patrão discutam as respectivas responsabilidades pelo fato. $O$ que se tem são apenas e eventualmente as declarações do patrão (ou de seu advogado) e da vítima acerca do fato. Não se observam também os longos depoimentos de testemunhas, que eram comuns nos processos criminais. A "teoria do fato do trabalho" se materializava do ponto de vista processual num procedimento extremamente célere. A lei determinava que o processo deveria terminar em no máximo 12 dias, contados a partir do acidente. Findo este prazo, deveria ser proferida sentença ordenando o pagamento devido (art. 21 da lei).

O processo era tão somente um procedimento judicial para obrigar o patrão ao pagamento. Consistia numa espécie de procedimento executivo. Neste ponto, a lei favorecia o trabalhador na medida em que não se previa a possibilidade de uma ausência de responsabilização patronal (com exceção dos casos já comentados de "força maior" ou "intenção da vítima"). Para que se configurasse o direito à indenização bastava apenas que se fizessem presentes no caso concreto: a) um operário; b) um patrão; c) um acidente. Não é por acaso que tanto a lei quanto o regulamento se iniciam conceituando juridicamente os institutos do "acidente", "patrão", "operário" e "obrigação de indenizar".

Cientes dessa condição, e diante do fato do acidente, alguns patrões procuraram fugir às suas responsabilidades, seja tentando desfigurar a sua condição de patrão, seja procurando descaracterizar a vítima da condição de operário a ele subordinado. Dona Carolina Lima Aguiar, dona da casa cujo assoalho era encerado quando da explosão que causou a morte da jovem Joaquina Camargo Ferreira, disse em juízo que a vítima não era mais sua empregada e que, apesar de lastimar sinceramente a desgraça de que fora vítima a 
menor, achava que não Ihe devia qualquer indenização. 0 juiz, corretamente, não aceitou o argumento, uma vez que o decreto considerava operário mesmo o que prestava serviço gratuitamente a alguém ${ }^{64}$.

Quando o patrão não podia negar a condição operária, procurava desfigurá-la alegando que não devia a indenização porque o operário não cumpria a sua função quando da ocorrência do infortúnio. O senhor Waldemar Heidtmam, proprietário da padaria "São Benedito" (Rua Prudente, n. 84) em 1920, defendeu-se em juízo alegando que o operário Frederico Vorgan - vítima de um esmagamento da mão direita, com perda dos dedos indicador, anelar e mínimo no cilindro de massa de pão - não se acidentou naquilo que era o seu ofício e portanto não deveria ser indenizado.

De acordo com o patrão, a vítima era "forneiro" e seu serviço consistia apenas em enfornar o pão e entregá-lo aos distribuidores, e não em trabalhar com a massa. 0 proprietário alega que tinha dois empregados suíços encarregados do serviço no cilindro de amassar pão, e que trabalhavam da meia-noite às cinco da manhã. Quando da ocorrência do fato, às sete de manhã, o cilindro já estava parado e os amassadores já tinham se retirado. Conta o patrão no processo que o acidente se deu por ter vindo à padaria naquela ocasião uma senhora que, entrando pelos fundos enquanto ele estava no balcão, pediu ao forneirovítima que amassasse a massa que trazia consigo, uma vez que os responsáveis já não estavam mais ali. O operário se disponibilizou a realizar o serviço e, segundo o patrão, fora vítima de acidente porque não tinha conhecimento do ofício. Diz ainda que lastima, mas não se julga obrigado a pagar a indenização ${ }^{65}$.

Os advogados dos patrões procuravam as brechas possíveis na lei de acidentes. Uma delas era a seguinte: o artigo $6, \S 1$, , do regulamento dizia estarem sujeitos ao regime da lei de acidentes no trabalho "as indústrias e os trabalhos agrícolas em que se empreguem motores inanimados (hidráulicos, térmicos, elétricos, a vento, a gás, a petróleo, a ar comprimido)." Quando o acidente ocorria no contexto de um trabalho agrícola com animais de carga, os patrões e seus advogados procuravam a isenção da responsabilidade alegando que veículos de tração animal não poderiam ser enquadrados na lei de acidentes, uma vez que eram de movimento animado.

\footnotetext{
${ }^{64}$ Caixa 15/A do 1o Ofício Cível de Piracicaba. ASAT - Joaquina Camargo (vítima) x Da. Carolina Lima Aguiar (patroa). 1920.

${ }^{65}$ Caixa 22/A do 1o Ofício Cível de Piracicaba. ASAT - Frederico Vorgan (vítima) x Waldemar Heidtmam. 1920.
} 
Foi exatamente isso que o advogado do Engenho Central (Société de Sucrerie Brésiliennes) disse nos autos de acidente de trabalho do operário Antônio Monteiro Azevedo em 1929. O operário estava carregando cana num carroção puxado por animais, quando o carro perdeu o freio e veio a despencar ladeira abaixo. $\mathrm{O}$ acidente causou a amputação da perna direita do trabalhador de 25 anos, e o advogado do Engenho disse que o acidente não seria indenizável pelas disposições gerais de direito comum. Mas, ao final, diz que o Engenho, "por liberalidade", não se opunha à indenização ${ }^{66}$.

Lázaro Dias Fernandes também tentou isentar-se da condição de patrão quando da morte de seu empregado Joaquim Desidério, alegando que era mais um companheiro que empregado, tanto que era até seu afilhado ${ }^{67}$. Além da estratégia da desfiguração de uma das condições fundamentais à indenização, as empresas e patrões lançavam mão de outros expedientes, como por exemplo a responsabilização da própria vítima pelo fato ou pela ausência de comunicação ao delegado.

O engenheiro da Companhia Paulista diz ao delegado no inquérito policial que o acidente de que foi vítima Benedito Victorino em 1921 não foi levado a conhecimento da polícia no tempo legal por incúria da própria vítima ${ }^{68}$. O patrão de Silvestre Selvagio, Hugo Bergamim, também alegou no processo que o operário despencou do andaime por sua própria culpa, e que não pagou as despesas médicas porque a vítima não lhe pediu ${ }^{69}$.

Na maioria dos processos, não constatamos a presença do advogado. Quando ele aparecia, era geralmente na condição de procurador das grandes empresas de Piracicaba, como a fábrica da Boyes, o Engenho Central e o Engenho Monte Alegre. Algum outro patrão poderia contratar o patrocínio do advogado para defender seus interesses em juízo, mas certamente esta não era a regra.

O operário, por sua vez, era representado judicialmente pelo promotor público. O art. 47 do decreto dizia que o representante do Ministério Público era obrigado a prestar assistência judiciária à vítima, uma fórmula que garantia a representação judicial daquele que não podia arcar com os custos de um advogado. O operário da Companhia Sorocabana,

\footnotetext{
${ }^{66}$ Caixa 22/A do 10 Ofício Cível de Piracicaba. Antonio Monteiro Azevedo x Engenho Central.1929.

${ }^{67}$ Caixa 22/A do 1o Ofício Cível de Piracicaba. AAT - Lázaro Dias Fernandes (patrão) x Joaquim Desidério (vítima).1922.

${ }^{68}$ Caixa 22/B do 1o Ofício Cível de Piracicaba. ASAT - Benedito Victorino (operário) x Cia. Paulista de Estrada de Ferro. 1921.

${ }^{69}$ Caixa 22/B do do 1o Ofício Cível de Piracicaba. ASAT - Silvestre Selvagio (operário) x Hugo Bergamim.1920.
} 
de propriedade do governo do Estado de São Paulo, perdeu dois dedos porque sua mão direita foi esmagada quando fazia o engate de dois vagões em maio de 1923. Invocou em juízo a assistência da promotoria, declarando ser pobre e precisar do dinheiro para manter os quatro filhos ${ }^{70}$.

O promotor em geral atuava no processo fazendo valer a prescrição legal que o obrigava a defender os interesses do operário-vítima. A primeira manifestação do Ministério Público geralmente era uma requisição de convocação das partes envolvidas em juízo para que declarassem se acordavam no pagamento e recebimento da indenização devida pelo acidente no trabalho. Caso não houvesse acordo, o promotor pedia para que o procedimento prosseguisse nos termos da lei de acidentes. Em seguida, os autos retornavam ao cartório, que os remetia novamente ao juiz. O juiz deferia, então, o pedido de convocação do Ministério Público, mandando expedir carta registrada para intimação dos interessados, patrão e vítima.

As manifestações do promotor em geral se davam no sentido de fazer valer na prática o valor indenizatório estipulado pela lei relativamente ao evento. Para o operário Eduardo Domingos, que perdeu um dos dedos da mão direita, pediu a indenização prevista pelo anexo do regulamento, de $15 \%$ a $40 \%$ sobre o salário mensal de $90 \$ 000$ ao longo de três anos ${ }^{71}$. Representando judicialmente o trabalhador agrícola Pedro Cunha, que tropeçou e foi vítima da grade que Ihe passou por cima do corpo, o promotor pediu à Companhia União dos Refinadores (propriedade da Pugliese \& Cia.) que esta custeasse o seu tratamento médico e hospitalar, além de garantir metade dos seus salários diários até que retornasse ao trabalho, conforme art. 20 do decreto ${ }^{72}$.

Mas em alguns casos, a assistência do Ministério Público parecia se mostrar frágil. Dois casos chamam a atenção. O primeiro deles é o do menor Guilherme Joós, que trabalhava na fábrica da Boyes e foi vítima de um acidente quando tentava puxar a "camilha" de uma máquina de fiação que não funcionava regularmente. A máquina prende a manga da sua camisa e prende o seu braço no cilindro, causando-lhe fraturas do úmero, terço médio, contusão na face e deslocamento, na parte superior, do pavilhão da orelha esquerda. O acidente havia se dado no dia 14 de outubro de 1919 . No dia 23 , o promotor se

\footnotetext{
${ }^{70}$ Caixa 22/B do 10 Ofício Cível de Piracicaba. IPAT - Governo do Estado de São Paulo x Domingos Gomes. 1923.

${ }^{71}$ Caixa 22/B do 1o Ofício Cível de Piracicaba. IPAT - Eduardo Domingos (vítima) x Emílio Bertozi. 1925.

${ }^{72}$ Caixa 15/B do 1o Ofício Cível de Piracicaba. IPAT - Pedro Cunha x Companhia União dos Refinadores. 1923.
} 
manifesta no processo dizendo que "não obstante estar sendo o suplicante tratado à custa de seus patrões da Boyes Irmão \& Cia., tem direito à indenização que se liquidar em ação sumária, segundo os termos da lei [...]."

O gerente da Boyes (Thomaz Eastwood), todavia, compromete-se a fornecer ao operário todo o tratamento médico e farmacêutico até o seu restabelecimento. O mesmo promotor, que havia afirmado que o jovem tinha direito à indenização (para além do tratamento médico e hospitalar devidos), "misteriosamente" desiste do depoimento das testemunhas arroladas e diz que as declarações do gerente punham fim à ação sumária. 0 juiz, ao final, não se atém a uma condenação apenas relativa ao tratamento e obriga a fábrica a pagar os salários integrais até o restabelecimento ${ }^{73}$.

O outro caso é o de Joaquim Desidério, que morreu sufocado com as sacas de cal. O patrão, como dissemos, havia alegado no processo ser a vítima mais um seu companheiro do que propriamente um empregado, uma vez que era seu afilhado. O pai (e beneficiário) da vítima se manifesta no processo, dizendo que não tinha nenhum desejo em receber qualquer indenização que proviesse do lamentável fato. O promotor consente com a manifestação e pede o arquivamento do caso. o juiz aceita o pedido, mas de forma reticente, manifestando seu descontentamento com o promotor. Diz que a lei de acidente no trabalho é lei de ordem pública, e que é nula de pleno direito qualquer convenção contrária e tendente a evitar a sua aplicação ou a alterar o modo de sua execução. Diz ainda que a própria vítima não teria o direito de renunciar às vantagens outorgadas, pedindo, por exemplo, uma indenização inferior à prevista em lei. E questiona: "terá o beneficiário o direito de desistir de qualquer indenização? Não será isso contrário ao que dispõe o art. 26 da lei?". Ao final, determina o arquivamento dos autos, "com o protesto de não ficar sancionado o precedente por este juízo" ${ }^{74}$. Por que, no caso, o promotor teria concordado com o pedido do beneficiário? Teria sido o assentimento dado em razão das relações de amizade entre patrão, vítima e beneficiário ${ }^{75}$ Estaria o promotor ainda orientado por uma visão liberal, que sobrepõe a vontade das partes à determinação da lei? Seria má-fé?

\footnotetext{
${ }^{73}$ Caixa 22/B do 1 o Ofício Cível de Piracicaba. ASAT - Guilherme Joós x Boyes. 1919.

${ }^{74}$ Caixa 22/A do 1o Ofício Cível de Piracicaba. AAT - Lázaro Dias Fernandes (patrão) x Joaquim Desidério (vítima).1922.

${ }^{75}$ A alegação de "amizade" entre patrão e empregado frequentemente esteve fundada mais numa autoimagem que o patrão fazia de si do que propriamente num vínculo afetivo que de fato unia ambos. De fato, num ambiente de trabalho com poucos empregados, as relações podiam ser mais estreitas, mas não se 


\subsection{RESULTADOS DOS PROCESSOS}

Já fizemos alusão aos resultados judiciais favoráveis aos trabalhadores nos processos por acidente no trabalho corridos na cidade de Piracicaba ao longo do período 1919-1930. A maioria dos processos chegava à quantia previamente fixada pela lei, sendo o patrão obrigado a indenizar o seu empregado ${ }^{76}$.

Para o caso de incapacidade total e temporária, a lei de acidentes previa o direito à indenização de metade do salário diário (art. 9o da lei e 20 do decreto). Mas o juiz condenava os patrões a pagarem esta indenização acrescida de uma diária de metade do salário/dia do operário, o que na prática correspondia ao pagamento integral do dia, como se o acidentado (incapacitado temporariamente para o trabalho) houvesse de fato trabalhado. Foi assim no caso do trabalhador vítima da grade de discos em 1923. Após a aferição judicial de que se tratava de um caso de incapacidade temporária, a Companhia União dos Refinadores foi condenada pelo juiz não apenas ao pagamento da indenização de 1\$400/dia (correspondente à metade do salário), mas a esse valor acrescido de uma diária de mais $1 \$ 400 /$ dia até o total restabelecimento ${ }^{77}$. Na prática, o trabalhador continuaria recebendo o seu salário integral de $2 \$ 800$. Do ponto de vista material, a indenização era muito pequena, mas é de certo modo intrigante uma condenação acima do limite prefixado pela lei.

Um valor maior do que o legalmente fixado também foi concedido em outro caso de incapacidade total e temporária, o de Silvestre Selvagio, que despencou de um andaime em 1920 no sítio de Hugo Bergamim. O juiz diz na decisão que o trabalhador percebia um salário de $4 \$ 000 /$ dia e que ficou 40 dias sem trabalhar. Pela lei, faria jus a uma indenização de

deve ver aí uma ausência de hierarquia. A imagem de "pai", "padrinho" ou "amigo" quase sempre se fundava numa ótica patronal paternalista em relação aos operários, e em alguns casos estes reagiam a ela, como por exemplo na greve de chapeleiros na cidade de São Paulo, em 1897, e na greve geral de Porto Alegre, em 1906. Cf. SIQUEIRA, Uassyr de. Entre sindicatos, clubes e botequins: identidades, associações e lazer dos trabalhadores paulistanos (1890-1920). Tese de Doutorado (História). Campinas: IFCH/Unicamp, 2008. p. 40. E também SCHMIDT, Benito Bisso, De mármores e de flores. A primeira greve geral do Rio Grande do Sul, Porto Alegre: Editora da UFRGS, 2005, p. 17.

${ }^{76}$ Foi assim com a Companhia Paulista de Estrada de Ferro, que foi condenada ao pagamento da indenização legal ao funcionário vítima de uma luxação escápulo-umeral direita, e também a arcar com os 10 dias em que seu operário, vítima do troly que repentinamente escapou por uma rampa, ficou sem trabalhar. Ao pagamento da indenização prevista em lei foi também condenado o patrão Domingos Ferreira Bento, cujo empregado foi vítima da pedra que despencou do barranco. Processos da caixa 15/B do 10 Ofício Cível de Piracicaba.

${ }^{77}$ Caixa 15/B do 1ㅇ Ofício Cível de Piracicaba. IPAT - Pedro Cunha x Companhia União dos Refinadores. 1923. 
$80 \$ 000$ (metade do salário por quarenta dias), mas o juiz condenou o patrão a um valor de $140 \$ 000,60 \$ 000$ a mais que o limite legal ${ }^{78}$. A Boyes também foi condenada pelo juiz a continuar pagando os salários integrais ao jovem Guilherme, temporariamente incapacitado para o trabalho ${ }^{79}$. O que haveria nessas situações? Seria uma condescendência do magistrado para com a situação de penúria dos operários?

Os patrões que tiveram operários mortos em acidentes também foram condenados ao pagamento. Izaías Emílio Romano, responsável pelo operário que faleceu ao despencar de um andaime de 20 metros quando trabalhava na cúpula da igreja da Nossa Senhora da Boa Morte, fez um acordo com o beneficiário da indenização ${ }^{80}$. Como vimos, a Bygton \& Cia., pertencente à Empresa Elétrica de Piracicaba, foi condenada a indenizar a morte de José Cristão, o Dr. Holger Jensen Kok, a 3:900\$000 pela morte de José Corrêa, e a patroa de Joaquina de Camargo, a uma quantia de $900 \$ 000$ pela morte da empregada.

Mas não devemos sobrevalorizar a vitória judicial dos trabalhadores. O resultado material ficava bem aquém de uma indenização compatível com a gravidade dos eventos ou mesmo com a dignidade humana do trabalhador. Com a quantia paga pela morte de Joaquina de Camargo, por exemplo, sua mãe e beneficiária ganhou o equivalente a nove meses de salário de um bom guardador de livros. O beneficiário de José Corrêa, por sua vez, recebeu de indenização o que receberia um contador em quatro meses de trabalho ${ }^{81}$.

A situação de injustiça material resta mais evidente se observarmos que o quantum indenizatório judicialmente estabelecido ficava também bastante aquém das possibilidades financeiras dos grupos econômicos de Piracicaba, como a fábrica Boyes e as usinas urbanas. As indenizações pagas pela Boyes a seus operários Maria Fiorim e Guilherme Jóos eram de fato insignificantes se considerarmos que seu capital girava por volta dos dois mil contos de réis. O jovem Guilherme, vítima da máquina de fiação, poderia comprar 100g de manteiga

\footnotetext{
${ }^{78}$ Caixa 22/B do do 1o Ofício Cível de Piracicaba. ASAT - Silvestre Selvagio (operário) x Hugo Bergamim.1920.

${ }^{79}$ Caixa 22/B do 1o Ofício Cível de Piracicaba. ASAT - Guilherme Joós x Boyes. 1919.

${ }^{80}$ Caixa 15/B do 10 Ofício Cível de Piracicaba. IPAT- Izaías Emílio Romano (patrão) x Josias Fischer (vítima). 1926.

${ }^{81}$ Equivalências estipuladas com base nas informações sobre salários contidas num documento intitulado "Condições de trabalho em São Paulo segundo o consulado norte-americano". (1922). In: PINHEIRO, P. S.; HALL, Michael M. A classe operária no Brasil: condições de vida e de trabalho, relações com os empresários e o Estado (Documentos, v. II). São Paulo: Brasiliense, 1981, p. 125-126.
} 
ou $400 \mathrm{~g}$ de café (por dia) com o valor da indenização que lhe foi paga pela Boyes ${ }^{82}$. Antônio Monteiro recebeu do Engenho Central o equivalente a quatro salários mensais de um contador pela perna direita que the fora amputada. Se os limites indenizatórios estabelecidos pela lei poderiam parecer razoáveis ou excessivos para os proprietários das pequenas oficinas ou empresas urbanas, eles eram bastante irrisórios para os grupos econômicos, não afetando de modo algum suas margens de lucro.

Pelo contrário, as grandes empresas possuíam seguros privados que garantiam o pagamento dessas indenizações. A proprietária da fazenda do Monte Alegre, a Companhia União dos Refinadores, assegurava os seus trabalhadores pela "Caixa Geral das Famílias"; a Boyes contava com a assistência da Companhia de Seguro Industrial, e o Engenho, com a da Companhia Segurança Industrial, todas com sede na cidade de São Paulo. As despesas com a seguradora eram incorporadas nos preços dos produtos e repassadas aos compradores, o que permitia manter intactas as margens de lucro.

O decreto permitia expressamente a contratação de seguro individual ou coletivo dos operários em companhia de seguro para indenização e socorro (art. 28, a), ou o seguro em sindicatos profissionais organizados conforme o decreto legislativo 1.637, de 5 de janeiro de 1907 (art. 28, b). O patrão não poderia descontar do salário dos operários qualquer contribuição destinada ao pagamento de despesas decorrentes do seguro (art. 28, §único), mas a lei não o impedia, naturalmente, de repassá-la aos compradores dos produtos.

Outras garantias jurídicas eram previstas pelo decreto: a submissão dessas companhias à fiscalização do Ministério da Agricultura (sem prejuízo da fiscalização da inspetoria de seguros); a necessidade de constituição de um fundo de garantia especial, cuja importância seria arbitrada pelo ministro da Agricultura, Indústria e Comércio; a obrigação de separar as operações de seguros contra acidentes de outras atividades econômicas, além da necessidade de remeter ao Ministério estatutos, balanços, relatórios, informações sobre taxas, cálculos da reserva de seguros, contratos e suas novações, modelo de apólices etc. (art. 29). Os sindicatos tinham as mesmas obrigações, com exceção da separação das operações de seguros, o que não se Ihes aplicava.

\footnotetext{
${ }^{82}$ Equivalência estabelecida conforme informações acerca de preços de produtos constantes de um artigo de jornal publicado em 1925 em A classe operária. "Um orçamento de classe média." (1925). In: PINHEIRO, P. S.; HALL, Michael M. A classe operária no Brasil, II, p. 130-131.
} 
O Estado poderia inclusive cassar a autorização das companhias de seguros e sindicatos profissionais que não cumprissem as condições previstas pelo regulamento (art. 32). E se as companhias ou os sindicatos não satisfizessem integralmente a vítima do acidente, esta poderia acionar o patrão através do Ministério Público (art. 33). Além disso, o patrão tinha o dever legal de comunicar à companhia de seguros ou aos sindicatos profissionais o acidente e suas circunstâncias dentro do prazo de 24 horas (art. 31).

Nota-se que a lei não conferia uma ampla margem de ação às companhias privadas. Pelo contrário, elas estavam submetidas às regras definidas pelo Estado, o que era mais uma garantia jurídica para o trabalhador. Essas garantias jurídicas, todavia, não impediram, na prática, que a questão dos acidentes se tornasse um negócio lucrativo para as empresas de seguros, e uma simples despesa extra (previamente estabelecida, e com limites bastante claros) a ser contabilizada pela empresa.

Por outro lado, a indenização consistia numa compensação financeira imediata, mas não garantia ao acidentado qualquer amparo material capaz de protegê-lo de um modo mais consistente. Se considerarmos o caso de incapacidade total e permanente, por exemplo, podemos ver que a indenização relativa a três anos de trabalho pouco valeria para aquele que ficaria impossibilitado ao trabalho por toda a vida. O mesmo se diga dos dois anos de salário pagos à viúva de um acidentado, que não mais disporia de seu auxílio para a composição da renda familiar; e dos três anos para uma família que não mais contaria com o trabalho do homem.

As incapacidades permanentes também foram reconhecidas pelo órgão judiciário de Piracicaba, embora de modo variável. Não se pôde verificar nas decisões a existência um critério básico. Mas se pôde notar que as decisões dos processos analisados jamais atingiram o limite indenizatório máximo relativo à gravidade da lesão. O manobrista Domingos Gomes, de 31 anos, perdeu dois dedos da mão direita por esmagamento, e foi indenizado em $25 \%$ sobre seus salários de três anos, quando a lei possibilitava uma indenização de $40 \%$ até $65 \%{ }^{83}$. Eduardo Domingos, que perdeu o indicador direito em 1925 e, portanto, tinha direito a uma indenização de até $40 \%$ sobre 3 anos de salário, recebeu metade disso ${ }^{84}$.

\footnotetext{
${ }^{83}$ Caixa 22/B do 1 o Ofício Cível de Piracicaba. IPAT - Governo do Estado de São Paulo x Domingos Gomes. 1923.

${ }^{84}$ Caixa 22/B do 1o Ofício Cível de Piracicaba. IPAT - Eduardo Domingos (vítima) x Emílio Bertozi. 1925.
} 
À primeira vista, a graduação do quantum indenizatório era estipulada em função do caso concreto. Mas dois casos chamam a atenção para uma condenação judicial abaixo dos limites fixados pela lei, em franca vantagem para os patrões. O primeiro é o de Frederico Vorgan, o forneiro da padaria que perdeu três dedos no cilindro da máquina. $\mathrm{O}$ acidentado fez um acordo com o seu patrão de $150 \$ 000$ por mês (ou seja, o salário mensal do operário) até o restabelecimento, e este foi homologado pelo juiz. Ocorre que o acordo não condizia com a perda de três dedos da mão direita.

O decreto estabelecia, no parágrafo 20 do art. 45 , que se houvesse acordo entre as partes, e uma vez homologado pelo juiz, o processo deveria terminar. Mas contra a possibilidade de abusos e pressões por acordos por parte dos patrões, determinava que sempre se que fizesse um acordo deveriam ser observadas as disposições da lei n. 3.724 e do próprio regulamento. Tecnicamente, o acordo deveria estar sujeito à tutela pública: a necessidade de respeito aos limites fixados pela lei, bem como a obrigatoriedade da chancela homologatória do juiz de direito indicam isso. Mas, na prática, o medo da perda do emprego ou mesmo as pressões extrajudiciais por parte dos patrões poderiam prevalecer.

No caso da padaria, o pagamento dos salários até o restabelecimento obviamente não respeita o regulamento, que prevê indenização de $15 \%$ a $40 \%$ sobre o salário de três anos para a perda do indicador direito, $5 \%$ a $20 \%$ para o anelar, e $5 \%$ a $20 \%$ para o mínimo. O § 20 do art. 21 do decreto dizia que no caso de perda de mais de um membro deveriam ser somadas as porcentagens relativas a cada um deles, sem contudo ultrapassar o limite de $60 \%$. Se o juiz fixasse o limite máximo, o operário faria jus a uma indenização de 2:700\$000. Considerando que o juiz concedesse os índices mais baixos para cada dedo (15\% para indicador, e $5 \%$ para o anelar e o mínimo) sobre o salário do operário (5\$000/dia), teríamos uma indenização de 1:125\$000 - sem considerar o esmagamento e uma possível anquilose da mão. O trabalhador tinha direito a essa indenização, que seria paga em razão da perda do dedo. Não há sentido em permitir um acordo "até o restabelecimento", uma vez que a lesão é permanente.

Um outro caso é o do funcionário do Engenho Central que teve a sua perda direita amputada. Para esses casos, a lei previa indenização de $55 \%$ a $60 \%$ sobre salários de três anos. O juiz, no entanto, condena o Engenho ao pagamento de apenas 50\%. Estaria a decisão influenciada pelo poderio econômico do Engenho? Não dispomos de elementos 
suficientes para responder, mas é curioso que tanto no caso do acidentado Guilherme Joós, quanto neste, temos uma autoridade pública (no primeiro, o promotor, e neste, o próprio juiz) deixando de concretizar o estipulado pela lei. E, nos dois casos, temos do outro lado grupos econômicos fortes, como a Boyes e o Engenho Central.

Por fim, deve-se mencionar que alguns processos terminavam sem conclusão, seja porque não havia prosseguimento da marcha processual, seja porque o operário expressamente retirava o pedido por haver se restabelecido. Em geral, eram os processos que envolviam lesões menos graves ${ }^{85}$. Quase a totalidade dos processos analisados que terminaram sem um pronunciamento da justiça se referiam a lesões produzidas no contexto da construção da linha férrea em 1922. Vemos ali ferimentos na mão em decorrência de batidas de pá ${ }^{86}$, lasca no pé ${ }^{87}$ e contusão por esforço com o braço esquerdo ${ }^{88}$.

A simples existência dos processos, no entanto, revela que mesmo aquelas pequenas lesões, como uma lasca no pé, chegavam ao conhecimento da polícia e da Justiça. Se as pequenas lesões chegam ao âmbito da Justiça, podemos ver nisso uma motivação do acidentado - ou de companheiros de trabalho, que poderiam auxiliá-lo nesse sentido - para fazer chegar a notícia do fato à autoridade pública competente, o que indica uma mobilização para a defesa de um direito reconhecido enquanto tal, a despeito da baixa gravidade da lesão e da insuficiência material da indenização correspondente.

A possibilidade de instrumentalizar uma lei contra o patrão, nesse sentido, é extremamente simbólica. Por outro lado, a interrupção do processo sem um resultado material favorável pode indicar várias coisas: pressão da empresa para que a pretensão fosse abandonada, medo de perder o emprego, ou mesmo desejo de abandonar a pretensão diante da melhoria do estado físico.

\footnotetext{
${ }^{85}$ Dos processos analisados, citamos como exceção a morte de Alberto Brasso, vítima de choque elétrico quando trabalhava em construção na Rua da Glória, em 1920. Caixa 15/B do 1o Ofício Cível de Piracicaba. ASAT - Alberto Brasso (vítima, por seu representante) x Napoleão Belluco (patrão). 1920.

${ }^{86}$ Caixa 15/B do 1 o Ofício Cível de Piracicaba. ASAT - Emílio Rodrigues x Cia. de Estradas de Ferro Paulista. 1922. O mesmo ferimento pode ser observado no processo de José Victorino (1922).

${ }^{87}$ Caixa 15/B do 1o Ofício Cível de Piracicaba. ASAT - Benedito Romão Fernandes x Cia. Paulista. 1922.

${ }^{88}$ Caixa 22/A do 1o Ofício Cível de Piracicaba. ASAT - Cia. Paulista de Estradas de Ferro x António Laurindo. 1922.
} 


\section{CONSIDERAÇÕES FINAIS}

Podemos dizer que a lei de acidentes no trabalho (e seu decreto regulamentador) representou para as classes trabalhadoras da Piracicaba da Primeira República um avanço em relação ao cenário anterior, no qual a vítima de acidente não poderia contar com nenhuma prestação patronal para minimamente aliviar a sua situação.

A lei criou mecanismos para a submissão do evento à tutela pública, permitindo que qualquer pessoa fizesse a comunicação do acidente ao delegado de polícia, responsável pela elaboração do inquérito; estabeleceu a obrigação de comparecimento da autoridade no local do evento e a elaboração de auto circunstanciado; garantiu a remessa do inquérito à instância judiciária independentemente de manifestação do acidentado; garantiu a representação do trabalhador em juízo pelo Ministério Público; estabeleceu um rito sumário, impondo o dever de julgamento do processo em no máximo 12 dias; estabeleceu a responsabilidade do patrão pelo evento e o pagamento de indenização independentemente de demonstração de culpa; conferiu ao crédito decorrente da condenação patronal um caráter privilegiado; ofereceu garantias ao trabalhador contra pressões patronais ao preconizar que acordos eventualmente estabelecidos entre a vítima e o patrão não poderiam contrariar o disposto na lei quanto às indenizações; não excluiu a responsabilização criminal do patrão; obrigou o patrão a publicá-la no local de trabalho, para que os operários tivessem consciência de seus direitos; sujeitou as seguradoras das empresas às suas regras; permitiu, pela primeira vez na História do Brasil, que patrões fossem efetivamente responsabilizados pelos acidentes.

Mas há um outro aspecto a ser ressaltado. Se a lei, com seu universo de garantias jurídicas e seu ideal indenizatório, representou um avanço em relação ao que até então se tinha, deve-se registrar que, sob a ótica do trabalhador, este avanço foi tímido, muito tímido. Dois mecanismos da lei faziam com que a indenização final fosse relativamente baixa, especialmente para aqueles grupos econômicos mais fortes, como a fábrica Boyes e os engenhos urbanos, controlados por capitais estrangeiros. O primeiro deles é o que atrelava a indenização ao salário da vítima, e não apenas à gravidade do evento ou à negligência do patrão. Os salários dos trabalhadores da Primeira República, em especial dos 
de Piracicaba da década de 1920, eram em geral bastante baixos, e proporcionavam indenizações igualmente baixas.

O segundo mecanismo prejudicial aos interesses dos trabalhadores e francamente favorável às classes patronais é a limitação imposta pela lei ao dever de indenizar. Os patrões, independentemente de sua eventual negligência ou gravidade do acidente, não poderiam ser responsabilizados por uma quantia superior a 2:400\$000/ano. 0 limite, assim como os valores previamente estabelecidos, servia bem aos propósitos de contabilização prévia dos eventuais acidentes, e o repasse das despesas daí advindas dava-se no preço dos produtos. Por outro lado, uma indenização, limitada que fosse, garantia o propósito primeiro manifestado pelo Centro Industrial quando de suas intervenções no processo de elaboração da lei de acidentes: estabelecer a harmonia entre patrões e empregados no ambiente de trabalho. Remediado pela indenização, o trabalhador se satisfaria de algum modo, deixando de reivindicar uma quantia maior.

Podemos dizer que aquilo que era o ponto positivo da lei - a responsabilização objetiva do patrão, independentemente de culpa - era também a sua fragilidade. Se a responsabilidade era prévia e objetivamente definida pela lei, ela retirava um eventual poder dos juízes de estabelecer uma indenização maior, apurada e definida de acordo com as peculiaridades de cada caso concreto. Além disso, se o empregado não necessitava demonstrar judicialmente a culpa do patrão, era como se do ponto de vista do Estado ela não existisse, restando frustrada a possibilidade de punições compatíveis com o grau de negligência patronal. Não foi por acaso que o Centro Industrial de bom grado se sujeitou à lei de acidentes. As classes patronais jamais se submeteriam a uma lei que desse poderes aos juízes para analisar e verificar eventuais culpas nos casos concretos, estabelecendo uma indenização compatível com as negligências patronais e a gravidade do caso. Os patrões queriam a segurança da previsão, e não abriram espaço para a possibilidade de uma intervenção judicial mais incisiva em favor do trabalhador. No caso da lei, o ideal de "segurança jurídica", propugnado pelas classes patronais, prevaleceu sobre o ideal de justiça.

Recebido em 17/12/2009

Aprovado para publicação em 24/02/2010 